\title{
ANALISIS SPASIAL BENCANA LONGSOR BUKIT TELOGOLELE KABULATEN BANJARNEGARA MENGGUNAKAN DATA FOTO UDARA UAV
}

\author{
Ruli Andaru ${ }^{1}$, Purnama Budi Santosa ${ }^{2}$
}

${ }^{1,2}$ Departemen Teknik Geodesi/Fakultas Teknik, Universitas Gadjah Mada, Indonesia Email: ${ }^{1}$ ruliandaru@ugm.ac.id; ${ }^{2}$ purnamabs@ugm.ac.id

\begin{abstract}
Spatial data is a very important role in emergency command and disaster management, before, during or post disasters. When a disaster occurs, the currently geospatial information is very needed: where the center of the disaster, the area affected, the volumetric of the landslide, what facilities are damaged, and determine the location of temporary shelters. This study examines and analyze the landslide in Banjarnegara 2014 before and after the landslide using Peta Rupa Bumi Indonesia (RBI) and the UAV Aerial Photos (Unmanned Aerial Vehicle). Data before the landslide obtained from RBI, while data after landslide obtained by performing aerial photography using fixed-wing UAV in December 2014 and August 2015. These aerial photos processing with photogrammetry to produce digital orthophoto and DEM (Digital Elevation Model). Orthophoto and DEM data is used to perform geospatial analysis in both $2 D$ and $3 D$. $3 D$ analysis obtained from the extraction of DEM elevation map data values appearance of the earth (RBI) and the UAV Aerial Photo. Analysis was conducted on the four components: contouring, terrain profile/cross section, slope/gradient, and volumetric (cut and fill). Readiness management of geospatial data and information is necessary to minimize losses and speed up the process of rehabilitation and reconstruction in the areas affected by the disaster. With this spatial analysis, the estimated of volume of landslides, mapping the facility affected, and the manufacture of the soil profile (high landslide, landslide affected area) can be performed quickly and accurately.
\end{abstract}

Keywords: telogolele, landslide, spatial analysis, UAV.

\section{PENDAHULUAN}

\subsection{Latar Belakang}

Bencana longsor merupakan salah satu bencana alam yang sering terjadi di Indonesia, seperti yang terjadi di Bukit Telogolele, Banjarnegara tahun 2014. Menurut data dari BPBD Kabupaten Banjarnegara, sebanyak 150 rumah tertimbun material tanah dan kurang lebih 105 warga menjadi korban jiwa dalam bencana tersebut. Morfologi di Bukit Telogolele secara umum berupa perbukitan dengan kemiringan landai hingga terjal. Material penyusun Bukit Telogolele adalah endapan vulkanik tua sehingga solum tanah tebal, terdapat pelapukan dengan kemiringan lereng bukit mencapai lebih dari $60 \%$, dan tidak ada terrasering di bukit tersebut. Tanaman yang tumbuh adalah tanaman semusim (palawija) yang ditanam dengan tidak rapat. Kondisi tersebut menyebabkan Daerah Telogolele merupakan daerah rawan longsor.

Pasca bencana longsor, data spasial menjadi data pertama yang diperlukan oleh instansi terkait dalam operasi tanggap darurat. Dengan data/informasi geospasial ini bisa dipetakan dengan tepat posisi pusat bencana terjadi, luas area yang terdampak longsor, fasilitas apa saja yang rusak, hingga penentuan lokasi hunian sementara yang aman bagi korban longsor. Data spasial memiliki peran besar dalam manajemen bencana, baik sebelum, pada saat maupun setelah bencana-bencana tersebut terjadi. Melihat pentingnya data spasial ini, maka diperlukan analisis terhadap data ini.

Beberapa penelitian penggunaan UAV untuk memetakan longsor diantaranya oleh Dąbski dan Maciej (2017), dimana menggunakan jenis $W$-ZOOM fixed-winged unmanned aircraft vehicle untuk melakukan deteksi dan analisis spasial longsor di Periglacial, Western Antarctic Peninsula. Sensor UAV yang digunakan adalah Canon 700D dengan jumlah foto sebanyak 766 buah foto dengan overlap $70 \%$ dan sidelap $60 \%$. Software ESRI dengan spatial analyst extension digunakan untuk mengekstrak nilai slope, aspect, dan kontur. Data orthophoto dan DEM digunakan untuk membuat vektorisasi patches (polygon) dari formasi lahan (sorted circles, stone fields, talus slope). Total terdapat 19 type formasi lahan yang dapat diidentifikasi dari data DEM dan orthophoto. UAV W-ZOOM mampu digunakan untuk memetakan dengan cepat, terbang dengan low altitude, dan efisien terutama untuk penyediaan data spasial formasi lahan rawan longsor.

Penelitian ini mengkaji dan menganalisis secara spasial bencana longsor Bukit Telogolele, Banjarnegara sebelum dan sesudah longsor berbasis data Peta Rupa Bumi Indonesia (RBI) dan foto udara dengan wahana UAV (Unmanned Aerial Vehicle). Data sebelum longsor diperoleh dari data Peta RBI, sedangkan data setelah longsor diperoleh dari akuisisi foto udara dengan wahana UAV. Tidak banyak sumber data spasial yang menggambarkan kondisi pasca longsor di Telogolele. 
Salah satu sumber data spasial yang ada pasca bencana longsor ini adalah Citra Satelit Pliades yang diakuisisi pada tanggal 16 Desember 2014 oleh LAPAN. Data Citra Pliades menunjukkan kondisi terkini Bukit Telogolele pasca longsor, akan tetapi pada citra ini masih terdapat kelemahan yaitu adanya awan yang menutupi sebagian besar area longsor dan tidak dilengkapi dengan data elevasi (DEM).

\subsection{Tujuan}

Tujuan penelitian ini, yaitu:

1. Menyediakan dan mengolah data geospasial sebelum dan sesudah longsor. Data spasial setelah longsor diperoleh dengan akuisisi secara langsung menggunakan wahana UAV;

2. Melakukan analisis spasial terhadap data sebelum dan sesudah longsor sebagai dasar kuantitatif dalam penilaian kerusakan dan pemantauan akibat bencana.

\subsection{Landasan Teori}

\section{UAV (Unmanned Aerial Vehicle)}

UAV terkadang disebut sebagai "Remotely Piloted Vehicle" atau dengan kata lain, pesawat terbang tanpa awak. UAV mampu membawa kamera, sensor, alat komunikasi, dan beberapa peralatan lain yang berfungsi untuk penginderaan jauh, mencakup sensor spektrum elektromagnetik, sensor biologis, dan sensor kimia serta untuk kegiatan intelligence, surveillance, dan reconnaissance (ISR). Sistem UAV-based fotogrametri memiliki kemampuan produksi yang hampir sama dengan penggunaan citra foto udara standar. Perbedaannya terletak pada kemampuan cakupan volume luas wilayah yang terbatas. Batasan cakupan wilayah sesuai dengan kemampuan jangkauan sistem kendali jarak jauhnya yang umumnya $<3$ km (Rokhmana, 2009). Penelitian ini menggunakan UAV jenis fixed wing.

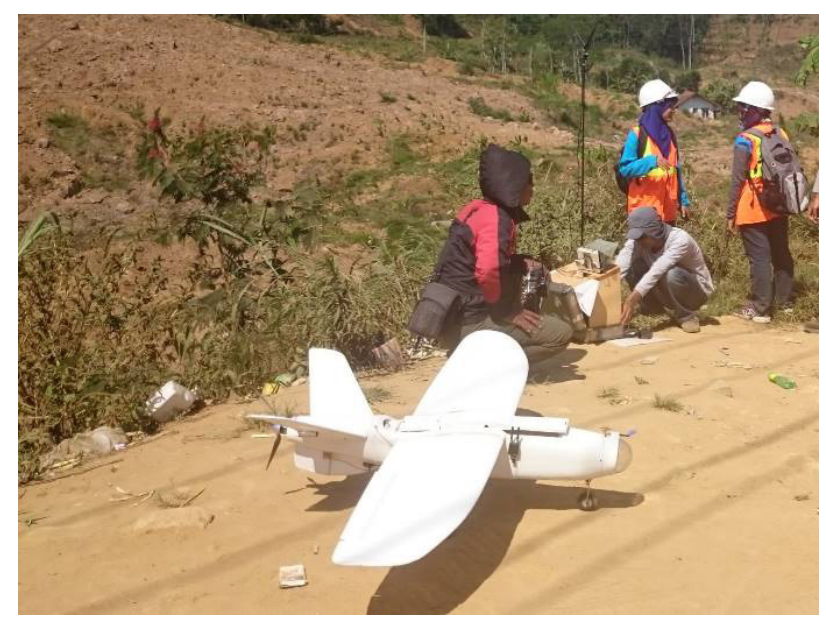

Gambar 1. UAV jenis fixed wing

\section{Instrumentasi Sistem Pemotretan Udara}

Sistem pemotretan udara terdiri dari dua bagian, yaitu sistem pada pesawat RC dan sistem pada ground station. Sistem pada pesawat RC antara lain berupa perangkat bantu navigasi dan perangkat pemotretan udara. Perangkat sistem UAV dilengkapi dengan sensor kamera jenis kamera digital pocket. Kamera yang digunakan pada penelitian ini adalah jenis SONY RX 100 dengan resolusi 20 MP. Agar foto digital hasil pemotretan memiliki koordinat, maka dipasang perangkat GPS pada badan pesawat. Posisi/koordinat GPS ini direkam dalam GPS logger untuk keperluan sinkronisasi terhadap tiap foto hasil pemotretan. Instalasi perangkat yang digunakan dalam pemotretan udara pada pesawat RC bisa dilihat pada Gambar 2 . 


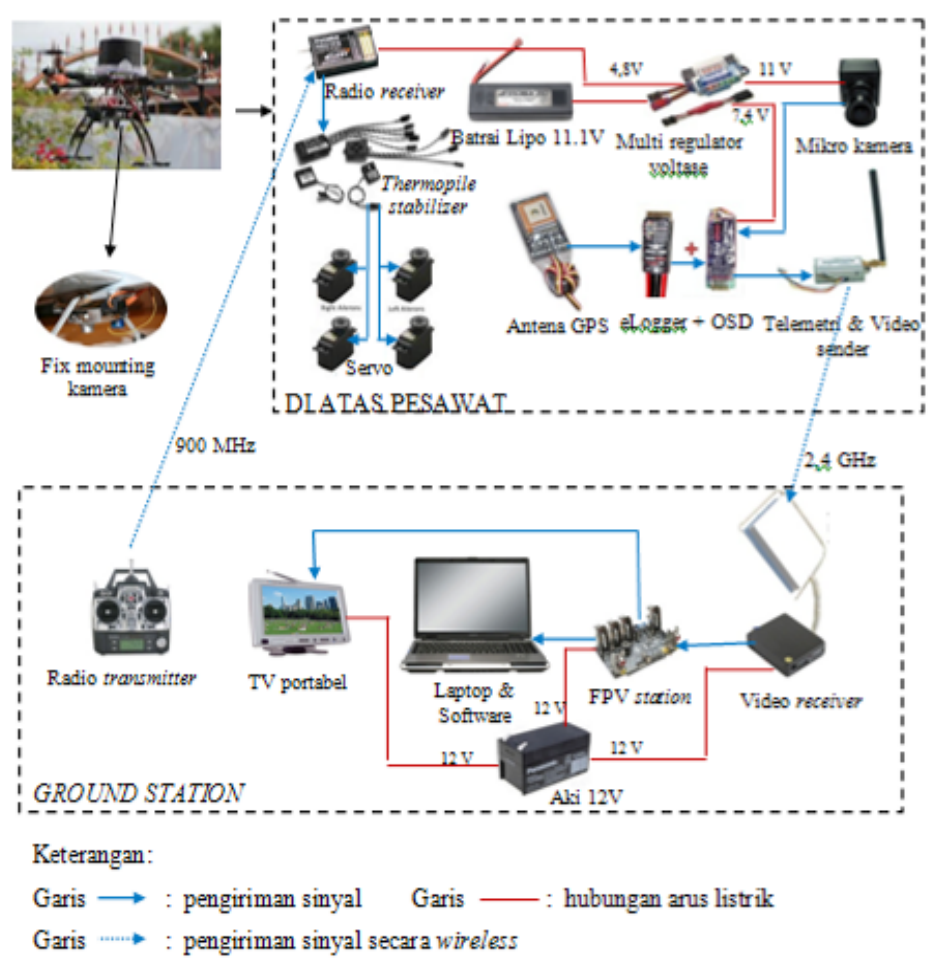

Gambar 2. Skema umum pesawat RC untuk pemotretan udara

\section{Ekstraksi DEM (Digital Elevation Model)}

Pada penelitian ini, data spasial (DEM dan orthophoto) setelah longsor diekstrak secara otomatis dari foto udara stereo. Data foto udara dari wahana UAV dapat diolah dengan teknik tertentu menjadi data 3D, salah satunya dengan menggunakan Metode SFM (structure from motion). Secara sederhana, SFM merupakan metode strategis yang mampu memodelkan objek dari citra dua dimensi menjadi bentuk tiga dimensi. Foto udara yang diolah dengan Teknik SFM (structure from motion) akan menghasilkan pointclouds/model 3D untuk seluruh obyek yang terekam dalam foto tersebut. Terdapat empat tahap utama dalam pembentukan model tiga dimensi pada SFM. Tahap pertama adalah tahapan untuk mentukan posisi kamera untuk setiap foto (alignment photo), sehingga tiap-tiap foto dapat ditentukan posisi relatifnya. Hasil dari tahap ini adalah tie point cloud dan konfigurasi posisi kamera.

Tahap kedua adalah pembentukan dense point cloud, yaitu pembentukan titik-titik yang mewakili bentuk permukaan dari objek. Titik-titik tersebut terbentuk dari piksel yang memiliki derajat keabuan yang sama dari foto yang bertampalan. Tahap ketiga adalah pembentukan mesh. Prinsip dasar pembentukan mesh adalah melakukan pembentukan poligon di permukaan obyek berdasarkan titik-titik dense point cloud. Poligon-poligon tersebut pada umumnya berbentuk segitiga dan segiempat yang kemudian digabungkan satu sama lain sehingga membentuk suatu permukaan obyek yang solid.

Tahap keempat adalah pembentukan tekstur dari objek yang dimodelkan. Pembuatan tekstur atau pemberian warna pada model tiga dimensi diperoleh dari foto-foto yang digunakan dalam pemodelan Hasil dari dense reconstruction adalah kumpulan titik-titik secara tiga dimensi atau disebut sebagai pointcloud yang menggambarkan koordinat $\mathrm{x}$, y dan z untuk semua obyek yang terekam dalam foto. Pointcloud inilah yang digunakan untuk membentuk DEM.

\section{Analisis Spasial}

Analisis spasial terdiri atas dua kata, "spatial" dan "analysis". Spatial menggambarkan referensi geografis pada suatu peta di mana terjadi suatu kejadian berdasarkan sistem referensi pada peta tersebut (Haining, 2004). Analisis spasial adalah suatu teknik/metode sistematis yang memproses nilai sebuah data dengan mengacu pada sistem koordinasi geografis. Analisis spasial dapat digunakan untuk mengevaluasi suatu kejadian/peristiwa secara perspektif virtual berdasarkan referensi permukaan bumi. Teknik ini dapat mengekstrak dan menciptakan informasi baru dari fitur geografis, mengevaluasi kesesuaian lokasi, melakukan estimasi dan memprediksi suatu peristiwa yang berkaitan dengan lokasi (Kaitsa, 2006). Keuntungan dari penerapan analisis spasial adalah kemampuan untuk mendapatkan informasi baru dari data yang ada, mengeksplorasi lokasi yang tepat, mengidentifikasi kemungkinan jalur terbaik, melakukan analisis jarak dan biaya, melakukan analisis statistik berdasarkan lingkungan lokal, interpolasi data, dan menggeneralisasi data (ESRI, 2007). 


\section{BAHAN DAN METODE PENELITIAN}

\subsection{Alat dan Bahan}

Peralatan yang digunakan dalam penelitian ini meliputi hardware untuk akusisi data lapangan dan software untuk pengolahan dan penyajian informasi:

1. Pesawat $U A V$ jenis fixed wing;

2. Kamera Canon SONY RX100 sebagai sensor;

3. Receiver GNSS Javad Triumph untuk pengukuran titik control;

4. Peta Rupa Bumi Indonesia (RBI) skala 1:25.000 area Banjarnegara;

5. Global Mapper 11 untuk mengkonversi format file R12/LT2 DXF menjadi format KMZ serta untuk registrasi mosaik foto udara untuk menampilkan data vektor jalur terbang serta menampilkan posisi wahana secara real time;

6. Agisoft PhotoScan, untuk ekstraksi kontur dan pembentukan DEM.

\subsection{Cara Penelitian}

Lingkup kegiatan penelitian meliputi dua kegiatan utama, yaitu akuisisi data lapangan dan pengolahan data (studio). Akuisisi data lapangan meliputi pengukuran titik kontrol dengan receiver GNSS dan pemotretan udara dengan wahana UAV. Sementara itu, pengolahan data meliputi pengolahan data foto udara UAV, pengolahan data kontur sumber data Peta RBI, dan analisa spasial. Secara garis besar tahapan pelaksanaan penelitian disajikan dalam Gambar 3.

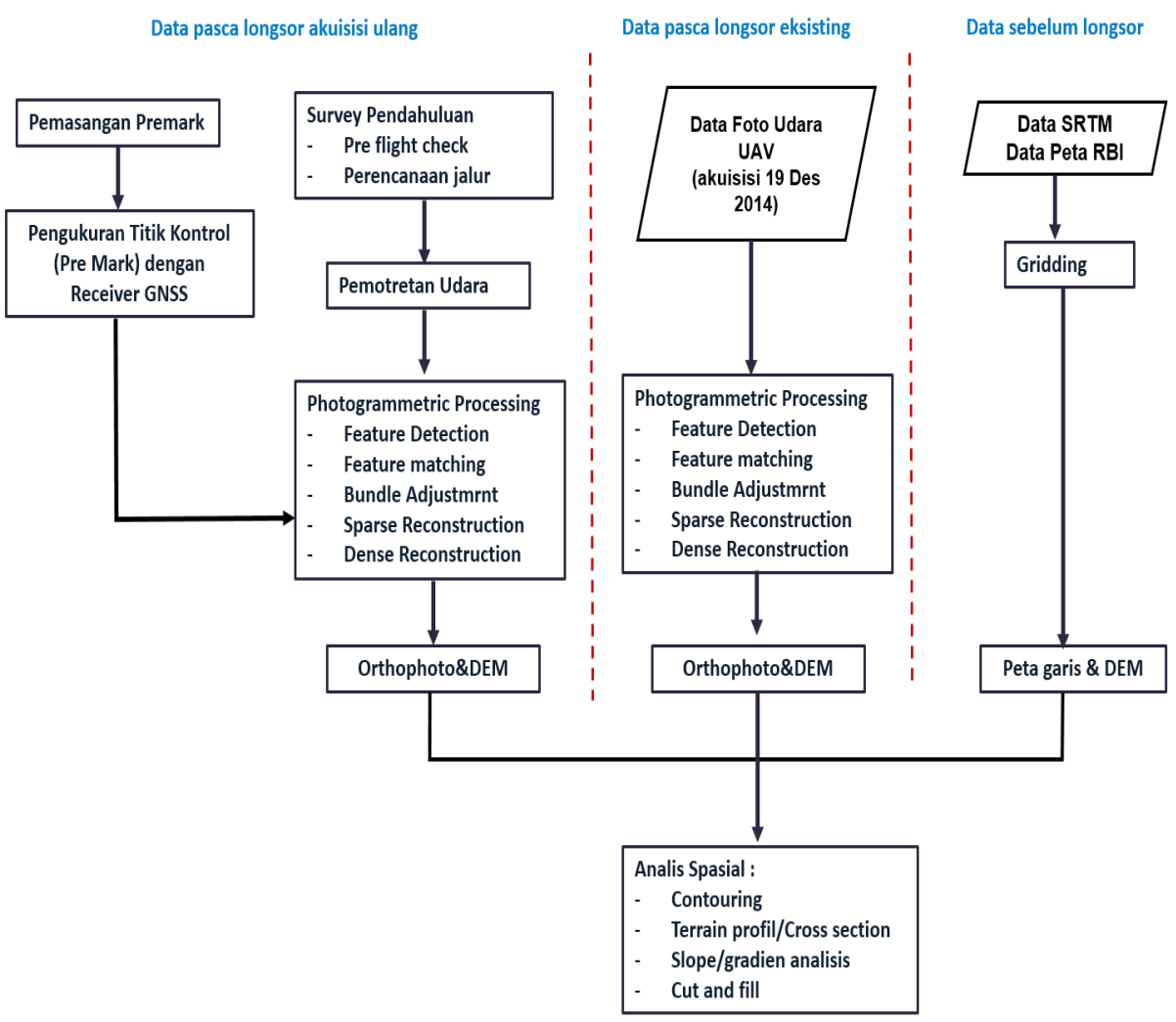

Gambar 3. Tahapan pelaksanaan penelitian

\section{UAV (Unnamed Aerial Vehicle)}

Untuk georeference dilakukan pengukuran GCP (pre mark). Titik ini dipasang tanda sebelum pelaksanaan pemotretan. Tanda (premark) dibuat dalam dimensi $1 \mathrm{~m}$ x $1 \mathrm{~m}$ dengan titik tengah diberi tanda warna hitam untuk memudahkan identifikasi titik pada foto udara.

GCP digunakan untuk mengikatkan hasil foto ke koordinat tanah. Titik ini diusahakan menyebar dan merata pada derah kajian. Untuk pengukuran koordinat titik ini dilakukan dengan menggunakan receiver GNSS type JAVAD Triumph 
1. Sebanyak tujuh titik GCP diukur menggunakan GNSS receiver.

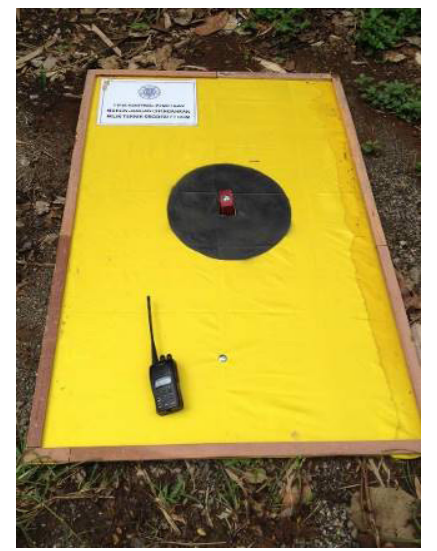

Gambar 4. Titik premark untuk GCP

\section{UAV (Unnamed Aerial Vehicle)}

Pemotretan wilayah longsor dilakukan pada ketinggian 400-500 m. UAV jenis fixed wing memiliki keterbatasan durasi penerbangan $( \pm 30$ menit) tergantung kapasitas baterai yang digunakan sehingga perlu beberapa kali mendarat untuk pergantian baterai. Untuk membentuk model 3D ataupun mozaik foto udara diperlukan foto-foto yang saling overlapping sehingga perlu untuk memperhatikan prosentase pertampalan antar foto. Pengendalian secara penuh pesawat dalam mengikuti jalur terbang mempunyai kendala yaitu efek perubahan arah angin dan suhu di angkasa terhadap perubahan arah dorongan angin pada pesawat yang sering terlambat diketahui dan diantisipasi melalui pengamatan live view video sender ataupun telemetri GPS navigasi di ground station.

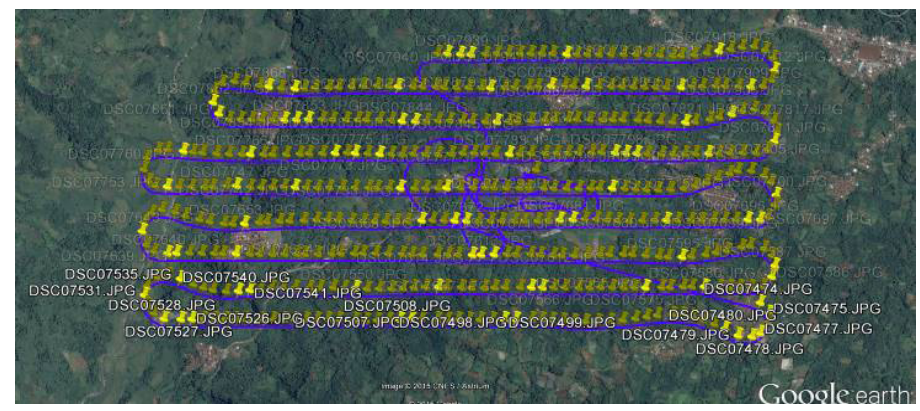

Gambar 5. Jalur terbang pesawat UAV

Pesawat fixed wing yang digunakan pada penelitian ini sudah memiliki fitur pengendalian otomatis sehingga lebih praktis, efisien, dan akurat dalam mengendalikan posisi pesawat supaya tetap pada jalur terbang yang sudah ditentukan. Dalam pelaksanaan pemotretan perlu diperhatikan kesesuaian arah pergerakan pesawat terhadap rencana jalur terbang yang telah dibuat sehingga diperoleh foto yang tajam, tidak kabur, dan memenuhi syarat minimal pertampalan (70\%).

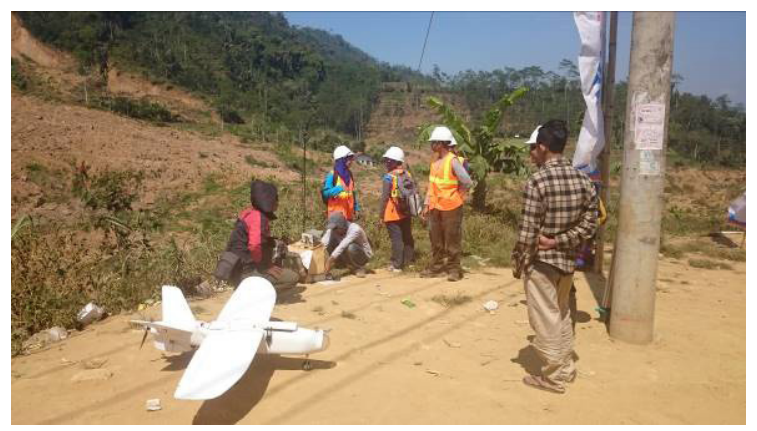

Gambar 6. Pesawat UAV type fixed wing 


\subsection{Pekerjaan Studio}

Dalam pekerjaan studio ini dilakukan pengolahan terhadap 3 buah data, yaitu:

1. Data RBI, Citra Bing/Goole Earth sebagai sumber data spasial sebelum longsor;

2. Data Foto udara UAV (akuisisi tanggal 20-21 Desember 2014) sebagai sumber data spasial setelah longsor;

3. Data Foto udara UAV (akuisisi akan dilaksanakan pada 25-26 Agustus 2015) sebagai sumber data spasial setelah longsor.

Ketiga sumber data ini digunakan sebagai dasar analisis spasial bencana longsor Banjarnegara. Tahapan pemrosesan fotogrametrik dengan SFM dilakukan melalui tiga tahapan, yaitu feature detection, feature matching, dan dense reconstruction. Pemrosesan ini dilakukan secara otomatis menggunakan Software Agisoft Photoscan Profesional.

\section{Hasil dan pembahasan}

Kegiatan penelitian ini menghasilkan:

1. Mozaik foto udara UAV area longsor Banjarnegara. Hasil ini diperoleh dengan cara menggabungkan beberapa foto yang saling overlap sehingga menjadi satu rangkaian foto;

2. Peta Orthophoto resolusi tinggi. Hasil dari pemotretan adalah image/foto dengan resolusi hingga $7 \mathrm{~cm}$. Hasil peta foto ini akan menggambarkan kondisi visual pasca longsor Banjarnegara;

3. Model 3D dan kontur sebelum dan sesudah longsor. Model 3D dan kontur direpresentasikan dalam bentuk peta situasi;

4. Hasil analisis spasial: data kontur, data profil/cross section, data slope/gradien, dan nilai volumetrik tanah longsor di Banjarnegara.

\subsection{Hasil Pemotretan UAV}

Pemotretan dilaksanakan selama dua epoch waktu, yaitu 20-21 Desember 2014 dan 25-26 Agustus 2015. Untuk area seluas 300 Ha dihasilkan kurang lebih 300 buah foto yang dipotret pada ketinggian terbang $300 \mathrm{~m}$ dengan 9 jalur terbang. Total jumlah foto adalah 642 buah dengan area terpotret seluas $700 \mathrm{Ha}$. Jarak antar exposure kamera adalah $50 \mathrm{~m}$ dengan tinggi terbang $300 \mathrm{~m}$. Hujan dan kabut menjadi kendala pemotretan di area bencana longsor Banjarnegara.

\subsection{Hasil Orthophoto}

Data pasca longsor diperoleh dari pengolahan data foto udara secara fotogrametris. Dari beberapa pasangan foto bisa dibentuk orthophoto untuk daerah longsor. Gambar 7 menunjukkan kenampakan area longsor Banjarnegara (akuisisi 20-21 Desember 2014), sedangkan Gambar 8 adalah visualisasi orthohoto UAV akuisisi 25-26 Agustus 2015.

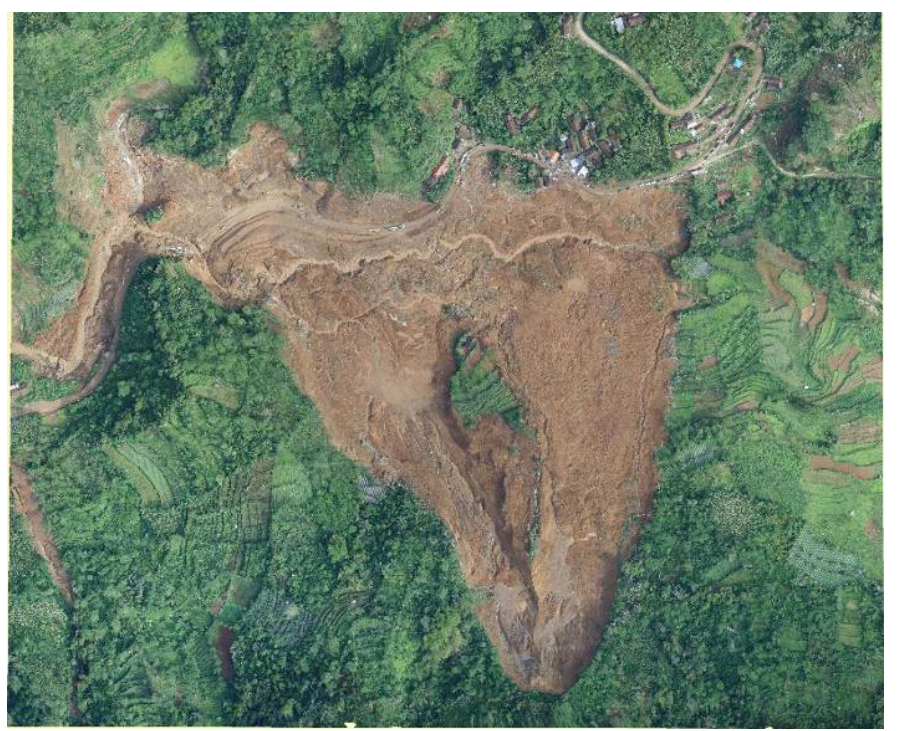

Gambar 7. Orthophoto area longsor Banjarnegara akuisisi 20-21 Desember 2014

Orthophoto epoch ke-2 diperoleh pada 25-26 Agustus 2015 untuk menunjukkan beberapa perubahan bentuk dan morfologi lahan area longsor. 


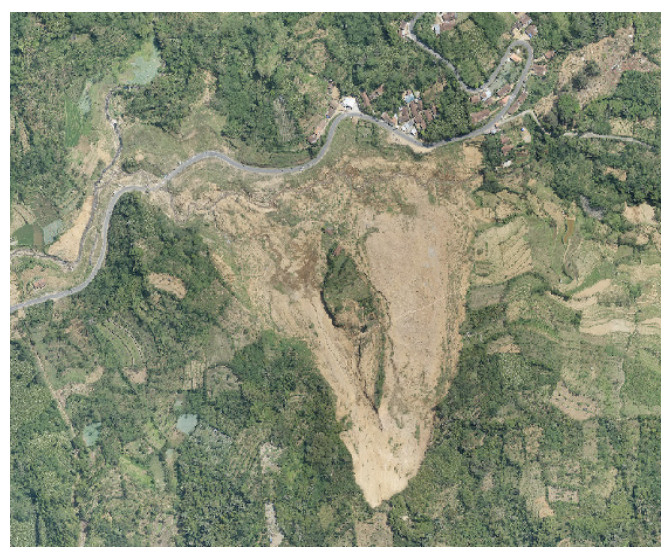

Gambar 8. Orthophoto area longsor Banjarnegara akuisisi 25-26 Agustus 2015

\subsection{Hasil Ekstraksi DEM}

Data yang diolah untuk penyediaan data DEM adalah data Peta RBI dan Foto udara UAV. DEM sumber Peta RBI diperoleh dari proses digitasi garis kontur pada peta tersebut yang kemudian dilakukan proses gridding. Untuk data DEM Foto UAV diperoleh dari proses ekstraksi otomatis dari sumber foto UAV. Tabel 1 adalah hasil visualisasi DEM dari ketiga sumber data tersebut.

Tabel 1. DEM sumber Peta RBI dan Foto UAV

\begin{tabular}{lll}
\hline No & Sumber DEM \\
\hline 1. & DEM: Sumber Peta RBI 1:25.000 \\
\hline 2. & (epoch 1) \\
& &
\end{tabular}

3. DEM: Sumber UAV (epoch 2)

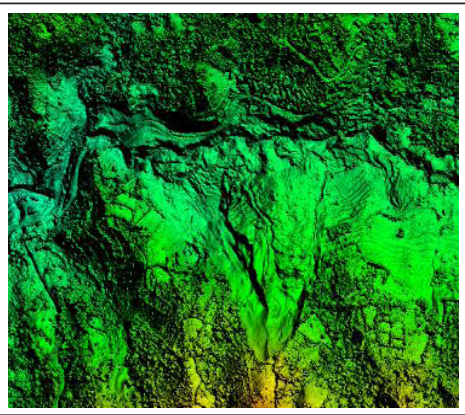




\subsection{Analisis Spasial}

Analisis spasial difokuskan pada beberapa aspek, yaitu analisa kemiringan elevasi bukit yang longsor, volumetrik longsoran, luasan terdampak longsor, luasan area yang mengalami perubahan longsor antara epoch 1 dan epoch 2 , dan volumetrik longsor susulan selama periode epoch 1 dan epoch 2.

\section{Analisa kemiringan elevasi bukit longsoran}

Dari data DEM Foto UAV dilakukan pembuatan profil melintang dari arah selatan-utara bukit longsoran. Puncak tebing ada di sebelah selatan (bawah) pada Gambar 9, sedangkan longsoran mengarah ke utara (atas). Jika dilihat dari elevasi pada hasil cross section ini, elevasi puncak ada di -/+ $1060 \mathrm{~m}$ dan elevasi bawah di $975 \mathrm{~m}$ sehingga tinggi tebing yang longsor di kisaran $85 \mathrm{~m}$.

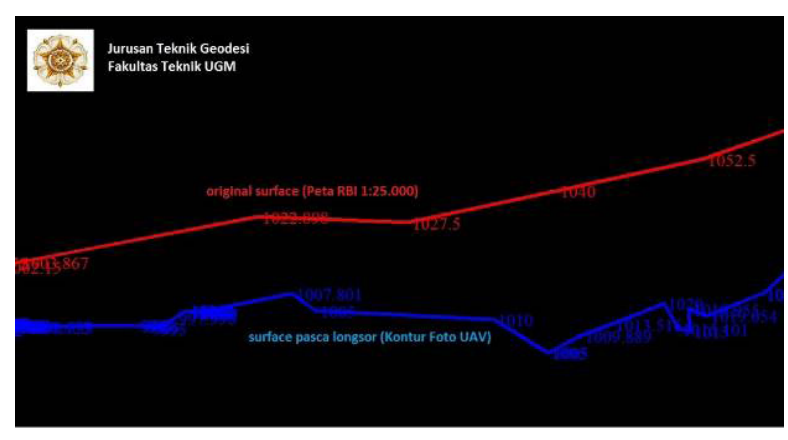

\section{Gambar 9. Section/profil area longsor Banjarnegara epoch 1 sumber UAV}

Jika dilakukan visualisasi data DEM (Peta Rupa Bumi Indonesia skala 1:25.000 dengan interval kontur 12,5 m) dan data DEM Foto UAV, dapat dilihat profil bukit sebelum dan sesudah longsoran, seperti disajikan pada Gambar 10.

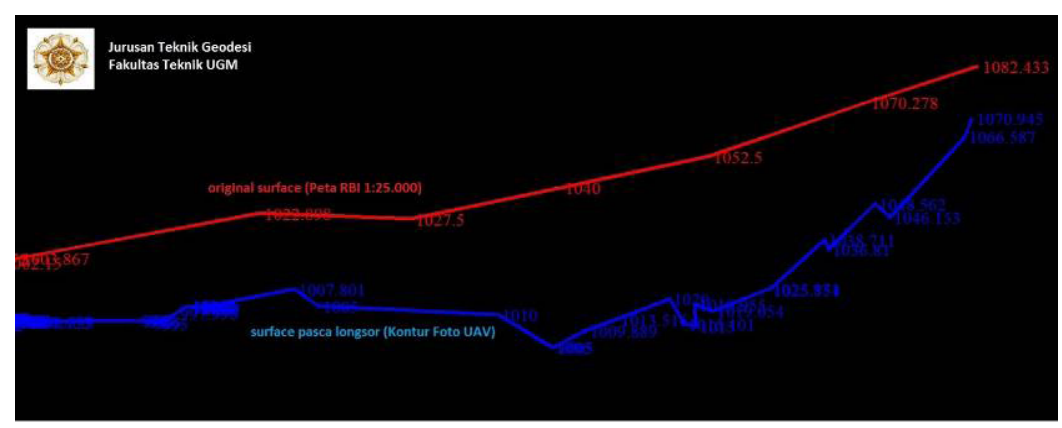

Gambar 10. Section/profil area longsor Banjarnegara Data UAV dan Peta RBI

\section{Analisa volumetrik dan luasan longsoran}

Secara teoritis, untuk menghitung volume longsoran dibutuhkan data pre longsor (original/base surface) dan data pasca longsor (design surface). Data yang digunakan berupa DEM RBI 25.000 dan DEM UAV epoch 1, kemudian dihitung volumenya. Dari hasil hitungan diperoleh volume longsoran adalah 1,032,791 $\mathrm{m}^{3}$ dengan luasan area longsoran adalah $74,598 \mathrm{~m}^{2}$.

\section{Analisa luasan area yang mengalami perubahan longsor antara epoch 1 dan epoch 2}

Ada dua epoch data pasca longsoran yang diperoleh dari penelitian ini yang bersumber dari pemotretan udara dengan wahana UAV. Gambar 11 menunjukkan kenampakan data epoch 1 dan epoch 2. Daerah yang mengalami perubahan longsor susulan adalah pada arah selatan (puncak bukit). 


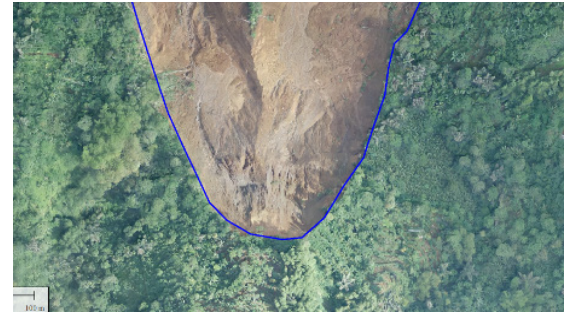

(a)

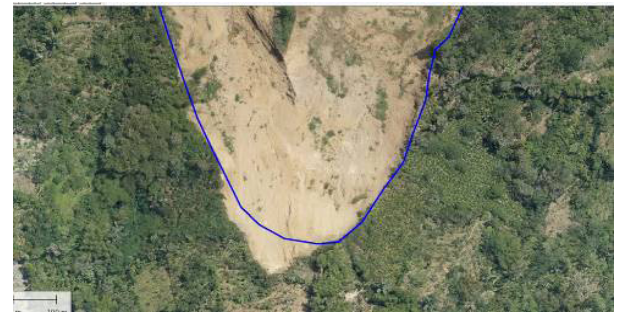

(b)

Gambar 11. Daerah longsor susulan (a) Data epoch 1 (20-21 Desember 2014),

(b) Data epoch 2 (25-26 Agustus 2015)

Daerah yang mengalami perubahan morfologi dan bisa dikatakan mengalami longsor susulan adalah seluas 965,34 $\mathrm{m}^{2}$ ditunjukkan pada Gambar 12.

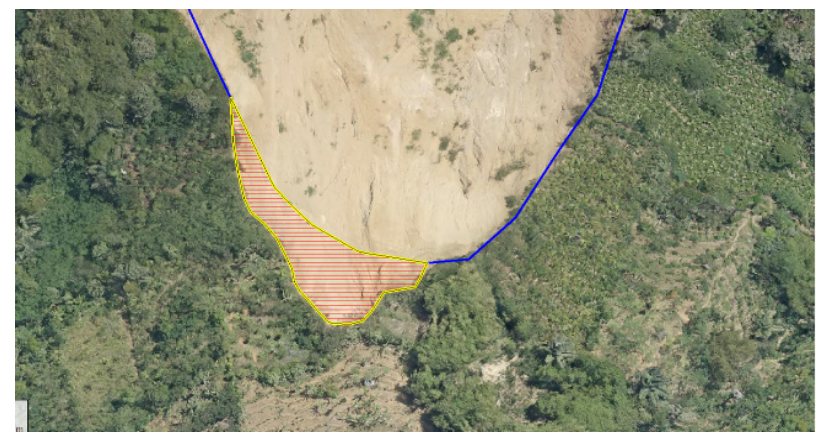

Gambar 12. Luasan daerah longsor susulan

Untuk melihat profil longsor susulan dan berapa dimensi/elevasi longsor susulan bisa dilakukan dengan melakukan profilling terhadap data DEM epoch 1 dan epoch 2. Warna cyan adalah profil bukit pada epoch 1 dan warna merah adalah profil bukit pada epoch 2. Dapat dilihat bahwa bukit mengalami perubahan elevasi dan guguran/longsor susulan dengan ketinggian longsor susulan mencapai $16 \mathrm{~m}$.

\section{Analisa volumetrik longsor susulan antara epoch 1 dan epoch 2}

Untuk menghitung volume longsor susulan dibutuhkan DEM epoch 1 dan DEM epoch 2. Data yang digunakan berupa DEM Foto UAV. Dari hasil hitungan bisa dilihat volume longsor susulan adalah sebesar 21,817 $\mathrm{m}^{3}$.

\section{KESIMPULAN}

1. Data Foto Udara UAV dapat digunakan sebagai salah satu sumber informasi spasial pasca bencana longsor dan dapat digunakan untuk proses analisis spasial. Penggunaan data Peta RBI sebagai data sebelum longsor dan data Foto UAV sebagai data pasca longsor secara efektif dan efisien bisa digunakan untuk pendekatan hitungan volumetrik dan analisa spasial lainnya;

2. Analisas spasial dapat dilakukan dengan menggunakan data Peta RBI dan Foto Udara UAV. Dari hasil hitungan diperoleh volume longsoran adalah $1.032 .791 \mathrm{~m}^{3}$ dengan luasan area longsoran adalah $74,598 \mathrm{~m}^{2}$, sedangkan dari dua buah epoch data Foto UAV diperoleh fakta bahwa longsor susulan akan terus terjadi di area Bukit Telogolele ini. Hal ini dibuktikan dengan jumlah volume longsor susulan adalah sebesar $21,817 \mathrm{~m}^{3}$.

\section{UCAPAN TERIMA KASIH}

Penulis mengucapkan terimakasih yang sebesar-besarnya kepada pihak BPBD Kabupaten Banjarnegara, PSBA (Pusat Studi Bencana Alam) UGM, serta LPPM UGM atas kerjasama, bantuan dana riset sehingga penelitian ini berjalan dengan baik. 


\section{DAFTAR PUSTAKA}

Anonim. (2012). Risk Analysis, Hazard Assessment, Information Based of Warning System And Communities Awereness Of Merapi_RAHASIA MERAPI.

Andaru, R. (2013). Scanning Obyek Arkeologi 3D Menggunakan Teknik Automatic Dense Surface Based Fotogrametr. The $1^{\text {st }}$ SNTT Annual Convention, Yogyakarta, Indonesia.

Andaru, R. (2015). Low Cost Rapid Mapping Area Gunung Kelud dengan Wahana Nir Awak. Laporan penelitian BPPTKG Yogyakarta, Indonesia.

Dąbski, Maciej. (2017). UAV-based detection and spatial analyses of periglacial landforms on DemayPoint (King George Island, South Shetland Islands, Antarctica). Geomorphology Journal, 290, 29-38.

F. Tsai, J.-H. Hwang, L.-C. Chen \& T.-H. Lin. (2010). Post-Disaster Assessment of Landslides in Southern Taiwan After 2009 Typhoon Morakot Using Remote Sensing And Spatial Analysis. Natural Hazards and Earth System Sciences, Nat. Hazards Earth Syst. Sci., 10, 2179-2190.

Haining, R. (2004). Spatial data analysis. Cambridge: Cambridge University Press.

JAEA. (1999). Clays in Natural and Engineered Barriers for Radioactive Waste Confinement

Kaitsa, G. (2006). GIS Glossary, Ohio: Delaware County, Ohio, USA. http://www.dalisproject.org/pages/glossary.htm\#s Accessed 02.04.15

Khomarudin, M. R, Suwarsono, Dini Oktavia Ambarwati \& Gunawan Prabowo. (2003). Evaluasi Kejadian Banjir Kampung Pulo DKI Jakarta dan Analisis Pengurangan Resikonya Berbasis Data Unmanned Air Vehicle (UAV) dan Penginderaan Jauh Resolusi Tinggi. Prosiding Deteksi Parameter Geobiofisik dan Diseminasi Penginderaan Jauh.

LAPAN. (2014). Perekaman berulang Citra Satelit Resolusi Tinggi Pleiades. http://www.inderaja.lapan.go.id/index.php/ subblog/read/2014/7/ Akses 02.03.15

Laksono, D.P. (2015). Pembentukan Model 3D dengan teknik Structure From Motion (SFM). Handout Workshop Ekstraksi Informasi dari Udara menggunakan wahana UAV, Yogyakarta, Indonesia.

Puntodewo. (2003). Sistem Informasi Geografis untuk Pengelolaan Sumberdaya Alam. Bogor: Center for International Forestry Research.

Rokhmana, C.A. (2010). Sistem Pemantauan Tata Ruang Kota dengan Wahana Udara Nirawak sebagai Penyedia Foto Udara Murah. Seminar Nasional Tata Ruang Wilayah, Institut Teknologi Malang.

Rokhmana, C.A. (2007). The Low-Cost Monitoring System for Landslide and Volcano with Digital Photogrammetry. Proceeding Joint Convention HAGI, IAGI, IATMI.

Thompson \& Heinze Gruner. (1980). Foundations of Photogrammetry. In, Chester C. Slama, Editor in Chief, Manual of. Photogrammetry. Falls Church: American Society of Photogrammetry, (Chapter I, P. 5).

Wolf, P.R. (1983). Elements of Photogrammetry. (2 ${ }^{\text {nd }}$ edition). New York: McGraw-Hill Book Company. 